\title{
Applying Blended Learning as an Effective Model for EFL Learners' Reading Comprehension
}

\author{
Abidin Pammu ${ }^{1 *}$, Hamzah A. Machmoed ${ }^{2}$, Ani Dyah Astuty ${ }^{3}$, Sitti Sahraeny ${ }^{4}$ \\ 1,2,3,4 Universitas Hasanuddin \\ *Corresponding author. Email: abidinpammu60@ gmail.com
}

\begin{abstract}
As an alternative solution to resolve various reading comprehension problems in the EFL context, it is necessary to implement a blended learning model which combines both online and face to face teaching modes. This study seeks to investigate the effectiveness of the blended learning model on students' reading comprehension in terms of the literal and interpretative level of comprehension. The research design was a quasi-experimental study using a sample of 60 students in the eleventh grade at SMAN 22 Makassar. Before the experiment was performed pre-test and post-test were conducted to measure students' reading comprehension. The findings indicated that students taught using a blended learning model, in the form of a face-to-face driver model supported by the Schoology platform, and had significantly made a greater improvement on reading performance. The findings contribute to pedagogical implications where teachers need to be made aware of such a model especially during the pandemic era of Covid-19.
\end{abstract}

Keywords: Blended Learning, Reading Comprehension, English Language Teaching

\section{INTRODUCTION}

The development of technologies and information has led to the emergence of various learning innovations in the field of education especially in English language teaching [1]. The innovative learning models emerged as alternative solutions to overcome various obstacles of traditional learning models in the EFL context. It appears that EFL students encountered problems in achieving comprehension in reading since English is not their first language. Some emerging issues such as students' lack of motivation, limited vocabulary, lack of prior knowledge as well as metacognitive strategies, and lack of target language exposure are confirmed to contribute to students' problems in comprehending academic English texts.

There have been greater numbers of studies already undertaken to investigate the effectiveness of blended learning in different EFL contexts [2]; [1]; [3]. Other studies with various platforms of innovations have also been investigated [4]; [5]; [6]; [7]; [8]. These studies confirm that blended learning is an enjoyable and powerful model in providing learners with significant language input. The Blended learning model has been considered as a promising teaching platform that addresses the issues in EFL reading comprehension since it provides flexibility and learning independence.

Previous studies have also confirmed if online learning invokes and generates students' motivation. Adzuhaidah M. Taha and Thang Siew Ming [9], for example, discovered that online learning not only promotes self-efficacy and autonomy, it also encouraged the students extrinsic and intrinsic motivation. Blended learning enables the teacher to integrate the traditional classroom with a computer to create a virtual classroom. Combining the traditional and online teaching modes allows language learners to interact with the language inside and outside of classroom settings to allow more learning autonomy. In addition, this model induces metacognitive strategies essential for both receptive productive skills which will, in turn, improve students' participation and engagement.

Considering its positive effect on the language learning process it is essential therefore that today's language teaching needs to engage technology by using the internet as a supporting process of generating language learning. Taking this into consideration, the study aims at gaining a coherent and systematic activity of language instruction that empowers a particular learning context concerning SMAN 22 Makassar by using Schoology which is integrated with face-to-face teaching.

This study ventured into reading comprehension for young learners which measures their literal and inferential level of comprehension. The critical level was not included since the basic competencies on the syllabus used in SMAN 22 Makassar for XI grade students cover only literal and inferential levels of comprehension. The focus of this study is on the use of the face-to-face driver model by using the platform 
named Schoology. Schoology has been considered as a more convenient teaching web layout with more features of which were not provided by other platforms.

\section{BLENDED LEARNING MODEL}

The term blended learning has been prevalent in EFL classrooms commonly used for specific English courses and at the tertiary level of education. It involves the blend or combination of traditional and computer-assisted language learning. It is a learning model that integrates innovation and technology through online learning systems with the incorporation of traditional learning. In addition, this model can be a means of interaction between teacher and student. This model also enables the teacher to create tasks aiming at challenging students' knowledge of reading being discussed in the classroom. To sum up, this model could invoke students' background knowledge necessary for the strengthening of the reading comprehension process.

Teaching reading as a receptive skill requires strategies before, during and after reading. The activity before reading is aimed at achieving the affective goals, which constitutes developing a positive attitude toward reading and empowering their reading strategies. Cognitive and metacognitive reading strategies can be empowered to achieve the reading goals. Text comprehension, for example, can include identifying the main idea, finding specific information, and inferring explicit information. Meanwhile, the post-reading activity involves the integration of reading skills to other language skills which may require both intensive and extensive readings.

\section{Table 1. Reading Instruction Using Blended} Learning Model

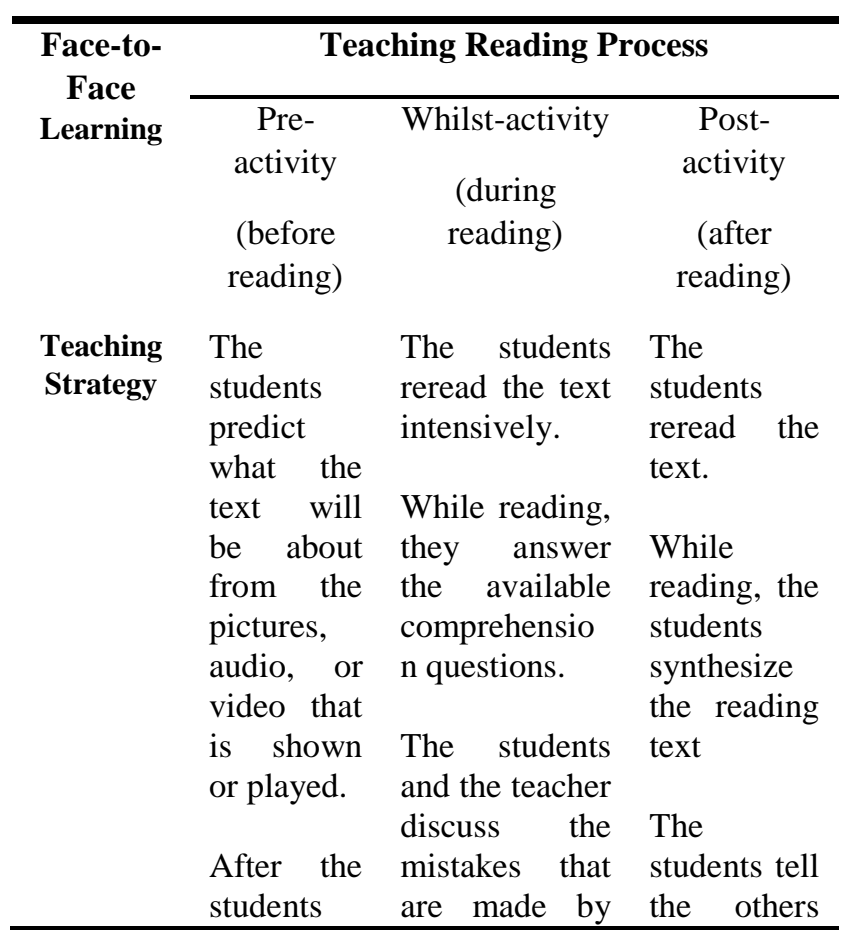

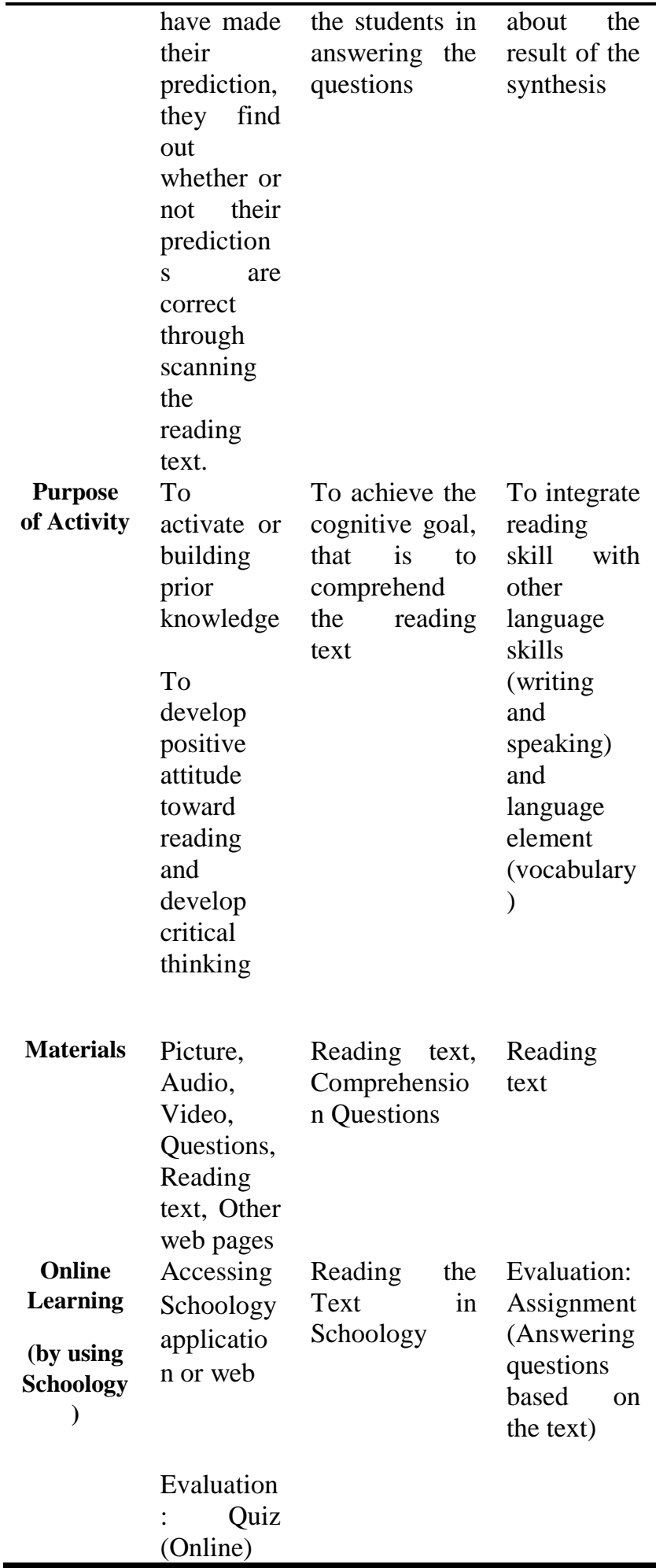

In this study, the researcher conducted the teachinglearning process face-to-face inside the classroom and utilizes Schoology as media for learning outside the classroom. Students can submit their tasks through that media on time and can utilize the class forum as a group discussion in addition to the face-to-face classroom. Application of Blended Learning Model increased students' reading comprehension in terms of the literal and inferential level of comprehension. 


\section{METHOD}

The quasi-experimental design was applied for this research. The students were divided into two classes, namely experimental and controlled classes. Pretest and posttest were performed on both classes to gain initial performance of the students' reading comprehension. The experimental class was given treatment using Blended Learning Model which is Face-to-Face Driver by using Schoology, whereas controlled class was taught reading in a traditional classroom format without online learning. It was expected that there was a difference in the achievement of reading comprehension between experimental and controlled classes.

To measure both the homogeneity of the learners and their progress, a reading comprehension test was administered before and after the intervention. Reading test consists of a narrative and report text, each test measures the literal and interpretative level of students' reading comprehension. To obtain information about the students' ability in reading comprehension after the treatments, a post-test of reading comprehension was also administrated. This test included the same content but employed different items. The total number of items was 25 which consist of 20 essays and 5 multiple-choice items.

In performing data analysis, the result of the students' test was scored. After scoring students' pretest and post-test answers, prerequisite analysis was employed by including normality test and homogeneity test. It was assumed that the normality of data distribution using normality test measured homogeneity of the population by using homogeneity test in SPSS 20 . After the normality and homogeneity test were performed, hypothesis testing was conducted.

\section{FINDINGS}

The total sample $(\mathrm{N})$, minimum and maximum scores, mean scores, and standard deviation were analyzed and displayed in the following table. The scores were obtained from pretest and posttest score of students in controlled class and experimental class.

Table 2 Descriptive Statistics of Students Pre and Posttest

\begin{tabular}{lccccc}
\multicolumn{7}{c}{ Descriptive Statistics } \\
& N & Min. & Max & Mean & $\begin{array}{c}\text { Std. } \\
\text { Dev. }\end{array}$ \\
& 30 & 28 & 99 & 62.43 & 22.639 \\
Pre-Test Experiment & 30 & 63 & 100 & 79.53 & 12.048 \\
Post-Test Experiment & 30 & 30 & 96 & 62.63 & 13.192 \\
Pre-Test Control & 30 & 50 & 98 & 67.23 & 12.244 \\
Post-Test Control & 30 & & & & \\
Valid N (listwise) & & & & & \\
\hline
\end{tabular}

The result of analysis of students' pre-test shows that in the experimental class, the minimum pre-test score was 28 , the maximum score was 99 and the average of score was 62.43 with standard deviation was 22.693. The minimum pre-test score in controlled class was 30 , the maximum score was 96 and the mean score was 62.63 with standard deviation was 13.192 .

The table also shows that post-test minimum score for experimental class was 63 , maximum post-test score was 100 and the mean score was 79.53 with standard deviation was 12.048. Meanwhile the minimum score of students' post-test in controlled class was 50 and the maximum score was 98 , the mean score was 67.23 with the standard deviation was 12.244

In this study, independent sample t-test was employed to measure significant difference on students' score in experimental and controlled class and the result is displayed in table 3

\section{Table 3 Group Statistics of Post-test in Experimental and Controlled Class}

The table above shows that the mean score of students' post-test in experimental class was 79.53 with standard deviation $=12.048$, whereas mean score of students' post-test in controlled class was 67.23 with standard deviation $=12.244$. It indicates that there was difference between their post-test scores as much as 12.3. The result of independent t-test can be seen in the following table

Table 4 The Result of Independent T-test

\section{Group Statistics}

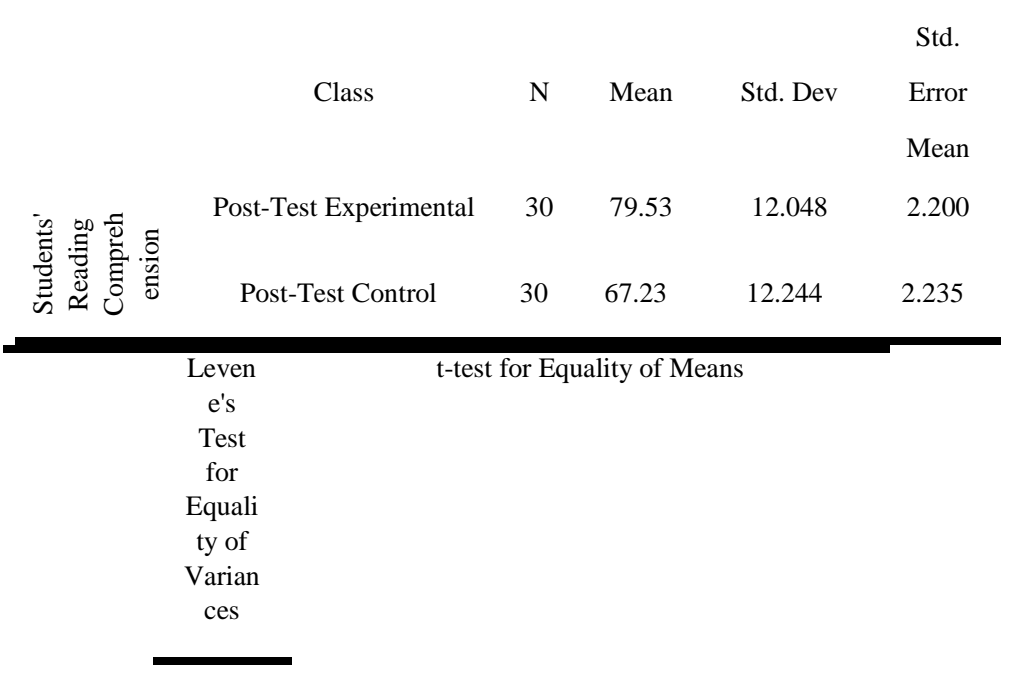




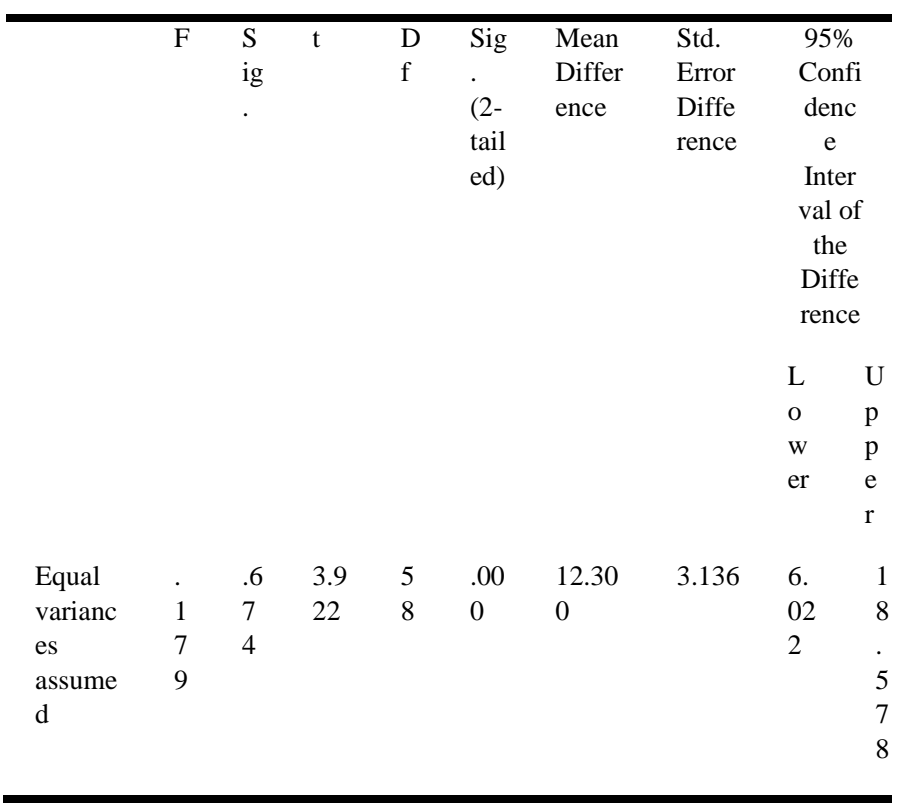

Based on the table, it was found that p-output was 0.000 which was lower than significance level of 0.05 with $\mathrm{df}=58$ and $\mathrm{t}_{\text {test }}$ value $=3.922$. The null hypothesis $\left(\mathrm{H}_{0}\right)$ was rejected and the alternative hypothesis $\left(\mathrm{H}_{\mathrm{a}}\right)$ was accepted since the $\mathrm{t}$ test was higher than ttable $(3.922>2.001)$. It could be stated that there was a significance difference between students' reading comprehension taught by using Blended Learning Model and those elwere taught using traditional model without online learning. The implementation of blended learning in experimental class maximized students' learning opportunities much better than the controlled group. It provided more time and space for teacher and students to interact, and with the interaction, students got involved more in learning. Meanwhile, in controlled group, the students were only able to interact with the teacher only during the learning process in face-to-face classroom which is limited in 90 minutes of formal instruction. The finding supports the ideas which confirmed that blended learning provides opportunities to practice the language beyond the class settings.

Blended learning model has yielded in a positive learning outcome to senior secondary students at SMAN 22 Makassar. The outcome was based on Paired t-test that had been employed to find out whether the model truly improved students' reading comprehension or not. The result of analysis also demonstrated that there was significant improvement on students' reading comprehension in experimental class after being taught using Blended Learning Model. The result was evident in the p-output which was lower than significance value $0.05(0.000<0.05)$ and $t_{\text {test }}\left(t_{0}\right)$ which was higher than $\mathrm{t}_{\text {table }}\left(\mathrm{t}_{\mathrm{t}}\right)(7.315>2.045)$.

The blended learning model has also yielded a clear performance between students in experimental class and controlled class. Based on the data, the mean score of students' pre-test in controlled class was 62.50, while after the treatment, the post-test result showed that students' mean score was 67.20. It indicates that there was an increase as much as 4.70. Unlike the controlled class, the difference between pre-test and post-test mean scores in experimental class was higher. The pre-test mean score of experimental class was 62.60 , while the post-test was 79.47. It shows that the increase of students' mean score in this class was 16.87 .

The statistical operation also shows if there is a difference between performance of experimental class students in pre-test and post-test. After the result of students' post-test in experimental and controlled class was compared it was found that there was a difference between experimental and controlled class of the posttest scores of 12.27. Both classes in this study received the same teaching materials but with different way of teaching instruction. The experimental class was supported by Schoology as a platform in the implementation of Blended Learning Model whereas the controlled class was not provided with online learning. It appears that the implementation of Blended Learning contributed pedagogically to the students' receptive skill especially their level of comprehension.

The result of the present study supports some of the previous research already undertaken which have examined the effectiveness of blended learning model. These previous studies demonstrated if the model enhances the students' performance as compared to students treated with traditional learning model. The results showed that there was a statistically significant difference on students' both pre and post test achievements between the class segments.

Overall analysis demonstrates that learners treated with blended learning platforms would improve in both learning performance especially reading comprehension levels and their reading strategies. learning approach, with the blended learning This finding warrants the needs of technology every teacher should adopt in order to constantly improve the performance of the students both receptive and productive skills. The finding is consistent with similar studies already undertaken in EFL contexts showing the very positive impact towards self learning development

\section{CONCLUSION}

This research has yielded in a positive outcome with reference to student's level of reading comprehension as indicated in their pre and post test score after the treatment has been completed. Findings emanating from the study indicated that both students in experimental and controlled group improved their ability of grasping literal and inferential comprehension with significant higher level in the experimental group. In other words, students treated with blended learning model, with face-to-face driver model supported by Schoology platform, had significantly greater improvement on the overall pre- to post-test. The results of this study are in conformity with many of the previous similar studies showing that there was 
significant improvement in terms of reading performance.

The present study has reinforced that blended learning model empowers teacher-student interaction, strengthens students' engagement and provide more accessible materials in learning. Blended learning has also enabled students to take more responsibility for their independent learning and to increase their involvement and participation. This study has in turn resolved the emerging problems faced by students under investigation concerning lack of teaching innovations. There is a need to take into account some factors for implementing the platform of Blended learning. Teachers, for example, need to take into account the students range of vocabulary that may impede their comprehension. Students' fluency, knowledge as well as teachers' ability in designing productive materials needs to be taken into consideration. Moreover, Blended Learning Model could be effective to help EFL learners improve their reading comprehension skill provided that necessary attention is given to suitability of materials and technology. Suitability of technology and teaching materials should also be taken into account with reference to students' needs and interests.

Despite the benefits of blended learning can have, it needs to be associated with some challenges EFL learners may encounter such as lack of computers and access of internet, lack of support and resources for course design, and poor teachers' technological skill . Overall, the findings reinforce the view that a blended learning model strengthens students' ability in reading comprehension. Hence, this study reinforces that teachers, regardless the challenges which may arise, inevitably must adjust their teaching to these new challenging teaching innovations and explicitly instruct their students how to make their learning most effective with the help of Information and Communications Technology (ICT).

Despite the positive impact of this study, major limitation may be evident, such as the research findings are based on the practice in a single school. Therefore future research area needs to be extended to a wider context of EFL situations and research methodology needs to adopt qualitative research paradigm in order obtain a more general picture of segments of learners the models may be applied for. In other there is a need to conduct other study on the use of blended learning in particular subject and broader context of learning situations. This study did not cover critical level of comprehension therefore it is important that the further research measure higher level of reading comprehension to obtain a more reliable and valid research findings.

\section{REFERENCES}

[1] Vasbieva, D.G., Klimova, I., Agibalova, Karzhanovand Bírová. (2016). Enhancement of Students' Vocabulary Learning through a Blended
Learning Approach, International Electric Journal of Mathematic Education, 11 (5), 1195-1203.

[2] Sari, I. \& Damayanti, M. (2017). Improving Students' Vocabulary Mastery by Using Blended Learning Model in State Polytechnic Padang. Script Journal of Linguistics and English Teaching, 2 (1), 101-110.

[3] Klimova, B. F., \& Kacetl, J. (2015). Blended learning and its current role in the teaching of foreign languages. Procedia-Social and Behavioral Sciences, 182, 477-481.

[4] Ekayati, R. (2018). Implementasi Metode Blended Learning Berbasis Aplikasi Edmodo. Jurnal EduTech, 4, (2).

[5] Onta, M. R. (2018). Efektivitas Penerapan Model Blended Learning dengan Menggunaka Media Pembelajaran Quipper School Ditinjau dari Motivasi Belajar dan Hasil Belajaar Siswa Kelas X TKJ-A SMK Asisi Jakarta Tahun Ajaran 2017/2018. Skripsi Fakultas Keguruan dan Ilmu Pendidikan Universitas Sanata Dharma Yogyakarta.

[6] Bataineh, R. F., \& Mayyas, M. B. (2017). The Utility of Blended Learning in EFL Reading and Grammar: A Case for Moodle. Teaching English with Technology 17(3).

[7] Kheirzadeh, S., \& Birgani, M. (2003). Exploring the Effectiveness of Blended Learning in Improving Reading Comprehension among Iranian EFL Students. Journal of Applied Linguistics and Research, 5 (1), 106-120.

[8] Vernadakis, N., Giannousi, M., Derri, V., Michalopoulos, Kioumourtzoglou. (2012). The impact of blended and traditional instruction in studentse performance. Procedia Technology, 1, $439-443$.

[9] Adzuhaidah M. Taha and Thang Siew Ming. (2014). Exploring Motivational Design and Motivation Types Facilitated By an Online Support System for Learning Literature. GEMA Online ${ }^{\circledR}$ Journal of Language Studies, 14( 2). 